\title{
Effect of Different Concentration of Commercial Seaweed Liquid Extract of Ascophylum nodosum on Germination of Onion (Allium cepa L.)
}

\author{
Akash Hidangmayum ${ }^{1}$, Richa Sharma ${ }^{2}$ \\ ${ }^{1}$ Student, Department of Biological Sciences, SHUATS \\ ${ }^{2}$ Assistant Professor, Department of Biological Sciences, SHUATS
}

\begin{abstract}
Seaweed extracts are used as nutrient supplements, biostimulants, or biofertilizers in agriculture and horticulture to increase plant growth and yield. In this study, we examined the effect of Seaweed liquid fertilizer(SLF) made from Ascophylum nodusum as biostimulants on the germination and growth of Onion (Allium cepa) under natural conditions. We assessed SLF at different concentrations (T0:0ppm, T1:3500, T2:4500ppm, T3:5500ppm, T4:6500ppm and T5:7500ppm) on germination percentage and growth parameters (shoot length, root length) of onion seedlings. Germination was conducted on strip of filter paper on various paper plates and observation for parameters viz; germination percent, shoot length, root length was recorded on $10^{\text {th }} \& 14^{\text {th }}$ day. Our results indicate that seeds treated with SLF at lower concentrations (5500ppm) showed enhanced germination percentage, shoot length and root length. The germination was observed higher in 73 (75\%) treatment in comparison to control and other treatments. The shoot length (7.72cm), root length $(1.02 \mathrm{~cm})$ was reported higher in $T 3$ treatment followed by $T 4$ in comparison to all other treatments. Decreasing trend on germination, shoot and root length is observed at higher concentration. The conclusion of the present study is that Seaweed extract may play effective role by using as a priming agent in improving seed germination and seedling growth of onion seeds.
\end{abstract}

Keywords: SLF (Seaweed liquid Fertilizer), Biostimulant, Ascophylum nodusum ,Biofertilizer

\section{Introduction}

Germination incorporates those events that commence with the uptake of water by the quiescent dry seed and terminate with the elongation of the embryonic axis (Bewley and Black, 1994). The seed is the structure in which a usually fully developed plant embryo is dispersed, and which enables the embryo to survive the period between seed maturation and seedling establishment, thereby ensuring the initiation of the next generation. The dry dormant seed is well equipped to survive extended periods of unfavorable conditions. Seed dormancy is defined as the failure of an intact viable seed to complete germination under favorable conditions, and is controlled by several environmental factors, such as light, temperature and the duration of seed storage (after ripening). Dormancy and germination are determined by the co-action of the growth potential of the embryo and the restraints imposed by the tissues surrounding it. The initial stage of vegetable growing is seed sowing and germination or emergence of seedlings. However, seedling emergence in soil could be suppressed by a number of unfavourable environmental conditions. Different pre-sowing seed treatments have been utilized to obtain fast and uniform germination or emergence. One of the most important pre-sowing treatments is known as seed priming. The general purpose of seed priming is to partially hydrate the seed to a point where germination processes are begun but not completed. Various seed priming techniques have been developed, including hydropriming (soaking in water), halopriming (soaking in inorganic salt solutions), osmopriming (soaking in solutions of different osmotica such as PEG- 8000), thermopriming (treatment of seed with low or high temperatures), solid matrix priming (treatment of seed with solid matrices) and biopriming (hydration using biological compounds). Therefore, any treatment which arrests seed germination could possibly be used as a priming treatment. Although very little work has been carried out on the priming of seeds with seaweed extracts and its effect on seed viability and the rate of germination, promising results have obtained in diverse species. The germination of onion seeds, especially under stressful conditions such as low temperature, continues to be a matter of great importance to growers who seed directly in the field. Seed priming is a presowing, controlled- hydration treatment in which seeds are exposed to an external water potential sufficiently low to prevent radical protrusion but stimulate physiological and biochemical activities(Bradford 1986). The process can improve speed and uniformity of germination, especially under adverse conditions such as low and high temperature, salinity and matric stress (Frett and Pill 1989, Pill and Finch- Savage 1988, Pill at al. 1991). The beneficial effects of seaweed products on the cultured plants are well documented. These products improve seeds germination, seedlings development, increase plant tolerance to environmental stresses (Zhang and Erivn, 2004 \& 2008), and enhance plant growth and yield (Hong et al., 2007; Zodape et al., 2008; Khan et al., 2009; Kumari et al., 2011). The seaweed extracts reported to improve seed germination in several species such as table beet(Wilezek $\boldsymbol{\&}$ Ng,1982) lettuce(Moller and smith,1998) and faba bean (El-sheekh and E-Saled,2000).

In modern Agriculture, extensive application of chemical fertilizers caused imbalance of soil nutrients. So, search for natural organic inputs for sustainable crop productivity has been emphasized. Seaweeds are rich source of growth promoting substances such as IAA, kinetin, zeatin and gibberellins auxins and cytokinins ; metabolic enhancers ; macro and micro elements, amino acids, vitamins and beneficial results from their use in crop plants like early seed germination and establishment, improved crop performance 


\section{International Journal of Science and Research (IJSR) \\ ISSN (Online): 2319-7064}

Index Copernicus Value (2015): 78.96 | Impact Factor (2015): 6.391

and yield, elevated resistance to biotic and abiotic stress and enhanced post harvest shelf life of seeds.

The aim of this study was to examine the effect of Seaweed Liquid Fertilizer derived from Ascophylum nodusum on seed germination and growth of tomato plants.

\section{Material and Methods}

Experiment was conducted to study the effect of different concentration of Liquid seaweed extract as priming agent for onion seed germination. The Seaweed extract used in this trial was 'Premium Liquid Seaweed' product of OrganicDews. Seed were first sterilized by $\mathrm{HgCl}_{2}$ and washed properly. Then seeds were soaked with seaweed extract in liquid medium for 6 hrs, later resins with distil water. The seed are spread on the strip of filter paper in various paper plates and observation for parameters viz; germination percent, shoot length and root length was recorded on $10^{\text {th }}$ and $14^{\text {th }}$ days. . Treatment details are given in table 1.

Table 1: Treatment details

\begin{tabular}{|c|c|}
\hline Treatment & $\begin{array}{c}\text { Concentration of Liquid Seaweed extract } \\
(\text { Ascophylum nodusum })\end{array}$ \\
\hline T0 & Normal water \\
\hline T1 & $3500 \mathrm{ppm}$ \\
\hline T2 & $4500 \mathrm{ppm}$ \\
\hline T3 & $5500 \mathrm{ppm}$ \\
\hline T4 & $6500 \mathrm{ppm}$ \\
\hline T5 & $7500 \mathrm{ppm}$ \\
\hline
\end{tabular}

\section{Result}

The present study shows that the percentage of seed germination was increased in treated plants when compared to control. The increased seed germination was recorded at lower concentrations of 5500ppm. The ameliorating effect of the SWE may be due to the growth hormones available which would have triggered the de novo synthesis of hydrolytic enzymes.

Our study on seed germination on onion provide better result than control. The germination percentage was significantly influenced by different treatments and shows positive influence on observed parameter. Observation recorded at $10^{\text {th }}$ days shows maximum germination $\%(75 \%)$ for $\mathrm{T} 3$ followed by $70 \%$ for $\mathrm{T} 1$. While minimum germination was occured in T0 followed by T2 and T5. Finally on $12^{\text {th }}$ day the germination $\%$ increased to maximum $75 \%$ for $\mathrm{T} 1$ followed by T3 (75\%) and least for T0 (50\%) (Figure 1). Shoot length at $10^{\text {th }}$ day was maximum $(5.57 \mathrm{~cm})$ in $\mathrm{T} 3$ followed by $\mathrm{T} 4(5.38 \mathrm{~cm})$ and minimum shoot development was in T0 $(3.86 \mathrm{~cm})$ followed by $\mathrm{T} 1(4.053 \mathrm{~cm})$ (Figure 2). Root length was also maximum $(0.76 \mathrm{~cm})$ for $T 3$ (figure $3)$. Finally on $12^{\text {th }}$ day T3 Shoot length and root length $(7.72$ $\mathrm{cm} \& 1.02 \mathrm{~cm})$ followed by T4 $(7.64 \mathrm{~cm} \mathrm{\&} 0.73 \mathrm{~cm})$ while minimum was recorded in T0 $(3.86 \mathrm{~cm} \& 0.63 \mathrm{~cm}$ ) (figure 2 \& 3).

\section{Discussion}

Present study was carried out to detect possible efficiency of Seaweed liquid fertilizer (SLF) derived from Ascophylum nodusum for use as biofertilizers for growing onion seedlings. Allium cepa seeds soaked with lower concentration of seaweed extracts showed higher rates of germination, while the higher concentration of the extracts showed lower rates of germination. Our results coincided with those of earlier studies on wheat (Soad, 2015) showing germination $93 \%$ when soaked in lower concentrations of seaweed extracts while at increased concentrations of the extract inhibits germination. Although in case of onion germination (T3-70\%) was less in comparison to that of wheat but significantly higher to control T0 (50\%).Similarly SLF treated seeds of green gram (Selvam, et al., 2013) shows good result with $100 \%$ germination in lower concentration of extract prepared from Ulva reticula and in cluster bean ( Thirumaram, et al., 2009) also reported similar findings while

using brown seaweed extract from Rosenvingea intricate. SLF treatment enhanced the rate of seed germination in green chilies and turnip (Dhargalkar and Untawale, 1980 ) and found that lower concentrations increase the germination percentage than the higher concentration. Similar observations on Cajanus cajan (Mohan et al., 1994), Zea mays, Elusine coracona and Pennisetum typhoides (Rajkumar Immanuel and Subramanian, 1999) Vigna sinensis ( Sivasankari, et al., 2006), Vigna mungo (Kalaivanan and Venkatesalu, 2012) and Zea mays (AlShakankery, et al., 2014).

Statistically significant differences were observed for shoot length and root length in SLF treated seeds. reported that Seaweed extract prepared from brown algae Rosenvingea intricata have good result on shoot length $(33.96 \mathrm{~cm})$ and root length $(17.23 \mathrm{~cm})$ on cluster bean(Thirumaram, et al., 2009) at the $20 \%$ extract solution. This result coincide with our current study on onion where maximum shoot length $7.72 \mathrm{~cm}$ (T3) and root length $1.02 \mathrm{~cm}(\mathrm{~T} 3)$ at lower concentration of $5500 \mathrm{ppm}$ which is significantly higher than control with shoot length 6.26 and root length $0.74 \mathrm{~cm}$. Similar finding were reported by using SLF from different algae (Dhargalkar and Untawale ,1983) on the growth of crops such as Capsicum frutescens. Brassica rapa and Anans comosus. The presence of plant growth regulators, trace elements, vitamins and macronutrients in the SLF enhances the growth of root length and shoot length of Vigna mungo (Challen et al., 1965). Similar results were recorded in Cajanus cajan (Mohan, et al., 1994), red gram (Venkataraman Kumar, et al., 1993), Rosenvigea intricata (Thirumaran, et al., 2009), watermelon (Abdel-Mawgoud , et al., 2010) and maize (Stephenson, 1974). The growth promoting factors like IAA and IBA, Gibberlins (A\&B), micronutrients, vitamins and amino acids have a marked influence on the germination rate whereas retarded growth effects at higher concentration can be SLF attributed by excessive hormones or high concentration of minerals present (Challen and Hemingway, 1965 ). In addition, seaweeds contain precursors of elicitor compounds that promote germination (Stephenson, 1974). 


\section{International Journal of Science and Research (IJSR) \\ ISSN (Online): 2319-7064}

Index Copernicus Value (2015): 78.96 | Impact Factor (2015): 6.391

Table 2: Effect of Liquid seaweed extracts on the seed germination and seedling.

\begin{tabular}{|c|c|c|c|c|c|c|c|}
\hline \multirow{2}{*}{ Treatment } & Concentration & \multicolumn{2}{|c|}{$\begin{array}{c}\text { Germination } \\
\%\end{array}$} & \multicolumn{2}{c|}{$\begin{array}{c}\text { Shoot length } \\
\text { (c.m) }\end{array}$} & \multicolumn{2}{c|}{$\begin{array}{c}\text { Root length } \\
\text { (c.m) }\end{array}$} \\
\cline { 3 - 8 } & & 10 days & 14 days & 10 days & 14 days & 10 days & 14 days \\
\hline T0 & Normal water & 50 & 50 & $3.86(\mathrm{c})$ & $6.25(\mathrm{e})$ & $0.53(\mathrm{~d})$ & $0.73(\mathrm{~d})$ \\
\hline T1 & $3500 \mathrm{ppm}$ & 70 & 75 & $4.05(\mathrm{c})$ & $6.50(\mathrm{~d})$ & $0.63(\mathrm{c})$ & $0.81(\mathrm{c})$ \\
\hline T2 & $4500 \mathrm{ppm}$ & 50 & 55 & $4.50(\mathrm{~b})$ & $6.92(\mathrm{c})$ & $0.65(\mathrm{bc})$ & $0.85(\mathrm{bc})$ \\
\hline T3 & $5500 \mathrm{ppm}$ & 75 & 75 & $5.57(\mathrm{a})$ & $7.72(\mathrm{a})$ & $0.76(\mathrm{a})$ & $1.02(\mathrm{a})$ \\
\hline T4 & $6500 \mathrm{ppm}$ & 60 & 65 & $5.38(\mathrm{a})$ & $7.64(\mathrm{a})$ & $0.73(\mathrm{a})$ & $0.92(\mathrm{~b})$ \\
\hline T5 & $7500 \mathrm{ppm}$ & 50 & 55 & $4.67(\mathrm{c})$ & $7.27(\mathrm{~b})$ & $0.71(\mathrm{ab})$ & $0.90(\mathrm{~d})$ \\
\hline
\end{tabular}

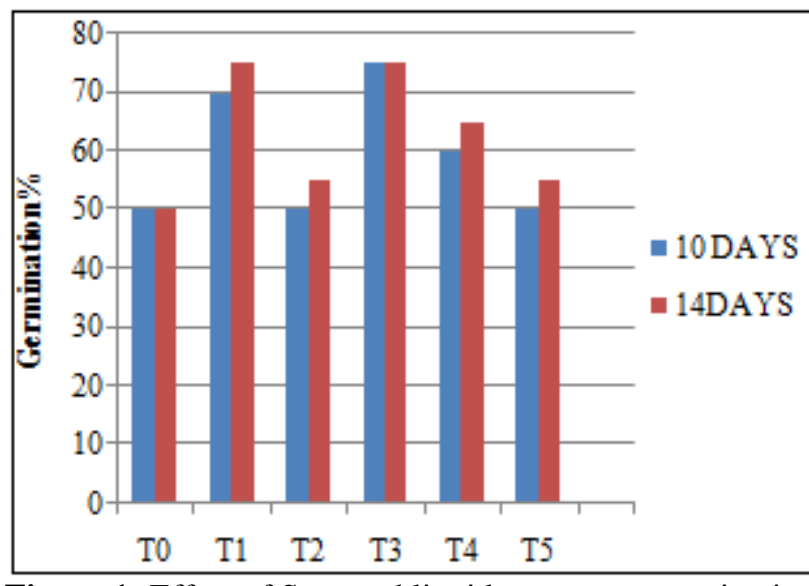

Figure 1: Effect of Seaweed liquid extract on germination of onion

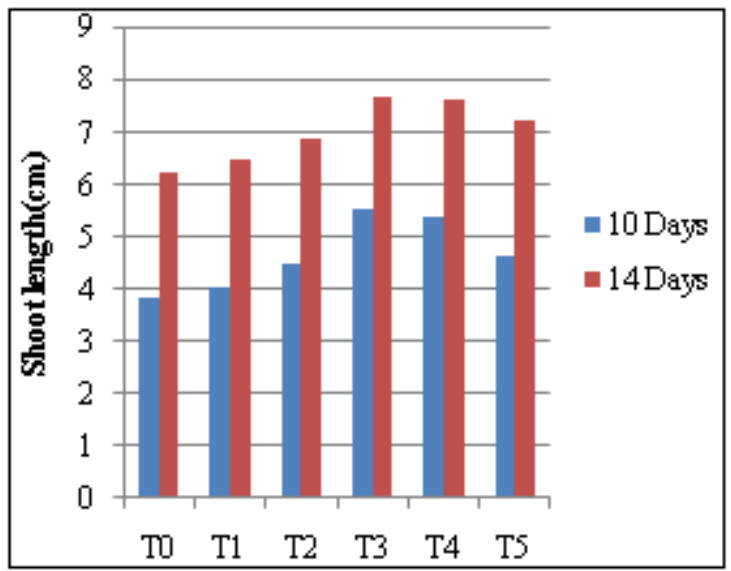

Figure 2: Effect of Seaweed liquid extract on Shoot length of onion

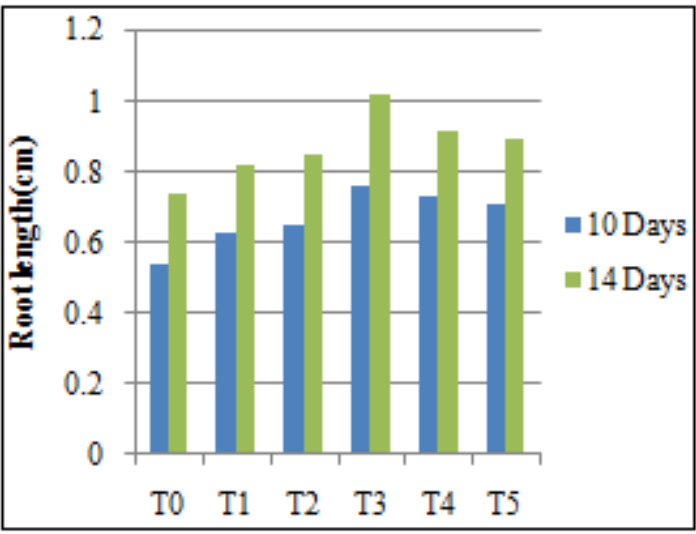

Figure 3: Effect of Seaweed liquid extract on Root length of onion.

\section{Conclusion}

The present study is an important step towards the utilization of the extracts of seaweeds derived from Ascophylum nodusum to improve the growth of onion seedlings. The presence of nitrogen, magnesium, potassium and some trace elements in seaweeds make an excellent choice as organic fertilizers. Thus, the practice of application of eco-friendly seaweed extract is recommended to growers for attaining better germination, growth of onion before transplanting. This study concludes that the seaweed liquid fertilizers are effective and low cost fertilizers that can be promoted as eco-friendly biofertilizers across India after further study.

\section{Acknowledgments}

I would like to thank to Department of Biological sciences Sam Higginbottom Institute of Agriculture, Technology \& Sciences (Deemed-to be UNIVERSITY) Allahabad-211007 and my Advisor for their valuable suggestions during my research work.

\section{References}

[1] Abdel-Mawgoud, A.M.R., Tantaway, A.S., Hafez, M.M., Habib, H.A.M., 2010. Seaweed extracts improves growth, yield and quality of different watermelon hybrids. Res J Agr Biol Sci., 6: 161-168.

[2] Al-shakankery, M., Hamouda, A., Ammar, M., 2014. The promotive effect of different concentration of marine algae as biofertilizers on growth and yield of maize plants. J. Chem. Biol Phys. Sci., 4(4): 3201-3211.

[3] Bewley, J.D., and Black, M., 1994. Seeds: Physiology of Development and Germination. (New York: Plenum Press)

[4] Bradford, K.J., 1986. Manipulation of seed water relations via osmotic priming to improve germination under stress conditions. HortScience., 21:1105-1112.

[5] Dhargalkar, V.K., Untawale, A.G., 1983. Some observation of the effect of SLF on higher plants. Indian J. Mar. Sci., 12(1): 210-214.

[6] Finch, W.E., and Mc Kec, J.M.T., 1988.Annals of applied Biology 113:415-424.

[7] Frett, J.J., and Pill, W.G., 1989. Germination characteristics of osmotically primed and stored impatiens seeds. Scientia Hort., 40:171-179.

[8] Hong, D.D., Hien, H.M. and Son, P.N., 2007. Seaweeds from Vietnam used for functional food,medicine and biofertilizer. J.Appl Phycol 19:817826. 


\section{International Journal of Science and Research (IJSR) \\ ISSN (Online): 2319-7064}

Index Copernicus Value (2015): 78.96 | Impact Factor (2015): 6.391

[9] Immanuel, R. and Subramanian, S.K. 1999. Effect of fresh extract and seaweed liquid fertilizer on some cereals and Millets. Seaweed Research and Utilization, 21 (1\& 2): 91-94.

[10] Kalaivanam, C. and Venkatesalu, V., 2012. Utilization of seaweed sargassum myriocystum extracts as a stimulant of seedlings of vigna mungo(L.)Hepper. Spanish journal of Agricultural Research .10(2),466470.

[11] Khan, W., Rayirath, U.P. and Subramanian, S., 2009. Seaweed extracts as biostimulants of plant growth and development. J. Plant Growth Regul., 28(4): 386-399.

[12] Kumari, R., Kaur, I. and Bhatnagar, A.K., 2011. Effect of aqueous extract of Sargassum johnstonii Setchell \& Gardner on growth, yield and quality of Lycopersicon esculentum Mill. J. Appl. Phycol., 23(3): 623-633.

[13] Moller, M. and Smith, M.L., 1998. The significance of the mineral component of seaweed suspension on lettuce (Lactuca sativa L) seedling growth. Journal of Plant Physiology, 153: 658 - 663.

[14] Mohan, V.R., Venkataraman Kumar., Murugeswari, R. and Muthusamy, S., 1994. Effects of crude and commercial seaweed extracts on seed germination and seedling growth in Cajanus cajan L. Phycos., 33: 47-51.

[15] Sahaya, A.X.G. and Louis Jesudass, L., 2007. Effect of seaweed extracts on cluster bean. Seaweed Research and Utilization., 29 (1\& 2): 85-87.

[16] Selvam, G.G., Balamurugan, M., Thinakaran, T. and Sivakumar, K. 2013. Developmental changes in the germination, growth and chlorophyllase activity of Vigna mungo L. using seaweed extract of Ulva reticulata Forsskål. Int Res J Pharma 4:252-254.

[17] Sivasankari, S., Venkatesalu, V., Anantharaj. M., Chandrasekaran,M., 2006. Effect of seaweed extracts on the growth and biochemical constituents of Vigna sinensis. Bioresour. Tehnol., 97(14): 1745-1751.

[18] Stephenson, W. A., 1974. Seaweed in agriculture and horticulture. Rateover, peruma valley. California, pp: 241.

[19] Soad, M. Mohy. El-din., 2015.Utilization of seaweed extracts as biofertilizers to stimulate the growth of wheat seedlings. Egypt .J.Exp.Biol.(Bot.),11(1):31-39.

[20] Thirumaran, G., Arumugan, M., Arumugam, R., Anantharaman, P., 2009. Effect of seaweed liquid fertilizer on growth and pigment concentration of Abelmoschus esculentus (I) Medikus. Am Eurasian J Agron., 2: 57-66.

[21] Venkataraman Kumar and Mohan, V.R. Murugeswari, R. and Muthusamy, M. 1993. Effect of crude and commercial seaweed extracts on seed germination and seedling growth in green gram and black gram. Seaweed Research and Utilization, 16 (1\&2):23-27.

[22] Wilczek, C.A., Ng, T., 1982.The promotion of seed germination in table beet by an aqueous seaweed extract. HortScience, 17:629-630.

[23] Zhang and Ervin, E. H., 2004. Cytokinin containing seaweed and humic acid extracts associated with creeping bent grass leaf cytokinins and drought resistance. Crop Sci., 44: -10.
[24]Zodape, S.T., Kawarkhe, V.J., Patolia, J.S. and Warade, A.D., 2008. Effect of liquid seaweed fertilizer on yield and quality of okra (Abelmoschus esculentus L.). J. Sci. Ind. Res., 67: 1115-1117. 